\title{
DEVELOPING STUDENTS' TRANSVERSAL COMPETENCES THROUGH CULTIVATION OF HEALTH LITERACY COMPETENCE
}

\section{ROZWÓJ PRZEKROJOWYCH KOMPETENCJI STUDENTÓW POPRZEZ PROMOWANIE WIEDZY \\ I UMIEJĘTNOŚCI MEDYCZNEJ}

\section{Tetyana Borova}

Simon Kuznets Kharkiv National University of Economics, Department of Pedagogy, Foreign Philology and Translation Nauky Ave. 9a, 61166, Kharkiv, Ukraine

Tetyana.Borova@hneu.net ORCID 0000-0003-1765-4425

\section{Viktoriia Petrenko}

Simon Kuznets Kharkiv National University of Economics, Department of Pedagogy, Foreign Philology and Translation Nauky Ave. 9a, 61166, Kharkiv, Ukraine

Viktoriia.Petrenko@m.hneu.edu.ua ORCID 0000-0001-7209-5107

\section{Tetiana Ved}

Simon Kuznets Kharkiv National University of Economics, Department of Pedagogy, Foreign Philology and Translation Ave.Nauky, 9a, 61166, Kharkiv, Ukraine

tetyana.ved@hneu.net O ORCID 0000-0002-4440-4248

\section{Vasyl Pyvovarov}

Yaroslav Mudryi National Law University, Department of Cultural Studies

st. Pushkinskaya, 77, 61024, Kharkiv, Ukraine

v.pyvovarov@ukr.net O ORCID 0000-0001-9642-3611

DOl: 10.2478/minib-2021-0008

\section{ABSTRACT}

The recognition that transversal competences are increasingly needed to face the challenges of the ever-changing world has given rise to work examining students' development of transversal competences (TVCs) during their university time. This approach argues in favor of embedding transversal competences as well as health literacy competence and subject-based competences in curricula. The mini-study presented herein first posits a logical model for the integration of transversal competences in university curricula, supplemented with a qualimetric model comprising 6 factors associated with transversal competences. The resulting tools for transversal competence evaluation and self-assessment were next applied in a pilot questionnaire study of a small group of management students at a local university. Overall, the findings support the claim that students' TVC development requires a new educational paradigm based on a holistic approach to competence-based learning that involves the harmonious development of a person's TVCs and subject-based competences. Moreover, the results may serve as 
a reference for future studies on transversal competences and health literacy in particular, as well as for teachers and researchers in related fields.

Key words: transversal competences, health literacy competence, subject-based competences, holistic approach, competence-based education, qualimetric model

\section{ABSTRAKT}

Założenie, że kompetencje przekrojowe są coraz bardziej potrzebne, aby stawić czoła wyzwaniom stale zmieniającego się świata, dało początek pracom badającym rozwój kompetencji przekrojowych (TVC) studentów podczas ich studiów. Podejście to przemawia za osadzaniem w programach nauczania kompetencji przekrojowych, a także kompetencji zdrowotnych i kompetencji przedmiotowych. Przedstawione tu minibadanie jako pierwsze zakłada logiczny model integracji kompetencji przekrojowych w programach nauczania uczelni, uzupełniony o model jakościowy obejmujący 6 czynników związanych z kompetencjami przekrojowymi. Wykorzystane narzędzia do przekrojowej oceny kompetencji i samooceny zostały zastosowane w pilotażowym badaniu ankietowym małej grupy studentów wydziału zarządzania na lokalnym uniwersytecie. Ogólnie rzecz biorąc, odkrycia potwierdzają twierdzenie, że rozwój TVC studentów wymaga nowego paradygmatu edukacyjnego opartego na holistycznym podejściu do opartego na kompetencjach uczenia się, które obejmuje harmonijny rozwój TVC danej osoby i kompetencji przedmiotowych. Ponadto wyniki mogą służyć jako punkt odniesienia dla przyszłych badań nad kompetencjami przekrojowymi a w szczególności świadomością zdrowotną, a także nauczycielom i badaczom pokrewnych dziedzin.

Słowa kluczowe: kompetencje przekrojowe, wiedza medyczna, kompetencje podmiotowe, podejście holistyczne, uczenie się oparte na kompetencjach, metoda jakościowa

JEL: $A 22, A 20$

\section{Introduction}

Much research in recent years has focused on developing health literacy competence (HLC), enabling people to exercise control over their health and health-related decisions. The importance of cultivating HLC in university students, through modifications in the design, scope, and content of curricula, has been demonstrated. Most institutions of higher education now integrate health literacy competence into their curricula through subjects included under co-scholastic areas such as "life skills" and "health and physical education" as well as into extracurricular activities, such as sports events. Nevertheless, HLC can also be integrated into curricula across subjects, through the development of students' transversal competences (TVCs). 
TVCs have been extensively studied by educators as competences vital for individuals as citizens to cope with global social, economic and technological changes and development. Therefore, their provision should be enhanced across all curricula, using innovative and student-centred pedagogical approaches. As a mini-study by Kristine Sorensen and other scholars (Sorensen et al., 2012) has shown, the definitions of the concept "health literacy" encompasses domains that nearly mirror the domains of transversal competences (TVCs): 1) critical and innovative thinking; 2) interpersonal skills; 3) intrapersonal skills; 4) global citizenship; 5) media and information literacy; and 6) physical health and religious values (UNESCO Office Bangkok and Regional Bureau for Education in Asia and the Pacific, 2015).

New educational policy documents emphasise that TVCs are needed to cope with the increasing challenges to the individual's physical, social and emotional health; thus, TVCs as well as HLC need to be further integrated into subject-based curricula. However, the relationship and balance between TVCs, HLC and subject-based competences in university curricula as well as the assessment of students' learning outcomes remain unclear.

The purpose of the article, therefore, is to propose a logic model for integrating transversal competences into university curricula, by relating curriculum activities to anticipated learning outcomes. The approach we employ in this study aims to cultivate students' HLC using the integration of TVC and Bloom', Dave's or Simpson's revised taxonomies into university curricula planning.

\section{Literature review}

The concept of "competence" is misused or used in a loose manner by scholars in many countries due to labour market demands. A competence is associated with a construct, a dynamic, complex combination of cognitive and metacognitive skills, knowledge and understanding, interpersonal, intellectual and practical skills, ethical values, attitudes, as well as the desire, motivation and experience to apply them in a particular situation of every day or professional life. A competence is gained through competencebased education, initial training and refined through practice. A competence 
demonstrates the individual's physical and intellectual quality to effectively perform the professional or everyday life activities or to meet the expectations of society (Tuning Academy Reference Points, 2009).

Traditionally, in higher education competences are classified in conceptual terms as being generic (common to any degree course) and subject-area related (specific to a field of study). In the last two decades, the conceptualization of generic competences has been widened and redefined. In the previous decade, educators used the terms "personal transferable skills", "graduate capability development", "generic capabilities", "graduate attributes movement", "generic graduate attributes", and so on to emphases the future graduates' ability to better address the demands of the everchanging labour market. Presently, the concept of "generic competences" has been redefined due to the realization of the UNESCO Roadmap for Implementing Global Action Programme on Education for Sustainable Development (2015). The challenges of the 21st century (global warming, shifts in demographic makeup, the rapidly changing global economy, the digital transformation, etc.) future generations will face require a new educational paradigm shift and a holistic approach. It should be focused on the development of the transversal (cross-cultural and transferable) competences needed by society to implement sustainability in all its domains, such as employment, education, well-being, environmental protection, economies and health. Thus, students' TVCs development aims to equip future graduates with competences required to interact effectively with society and the planet in the following dimensions: economic, social, cultural and ecological. Accordingly, TVCs are often also labelled as 21st century skills, soft skills, non-cognitive skills or skills to survive (Table 1). 


\section{Table 1. Different Views on Transversal Competences' Definitions and Skill Taxonomy}

\begin{tabular}{|c|c|c|c|}
\hline Author & Year & Definition & Skills \\
\hline 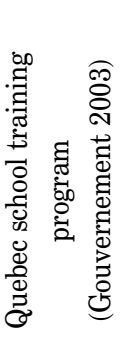 & 2003 & $\begin{array}{l}\text { Transversal competences refer to } \\
\text { additional set of skills that support the } \\
\text { development of professional, subject- } \\
\text { based skills }\end{array}$ & $\begin{array}{l}\text { Intellectual skills: problem solving, } \\
\text { critical thinking, creative } \\
\text { thinking.Methodological skills: } \\
\text { communication and information } \\
\text { technologies.Personal and social skills: } \\
\text { ability to cooperate and self-development } \\
\text { Communication skills: ability to } \\
\text { communicate }\end{array}$ \\
\hline 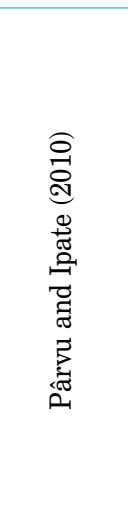 & 2010 & $\begin{array}{l}\text { Transversal competences refer the values } \\
\text { and attitudes that go above of a given } \\
\text { specific field or study program and that } \\
\text { have a transdisciplinary character. } \\
\text { Transversal competences deal with } \\
\text { personal attributes of a cognitive, social, } \\
\text { attitudinal or evaluative nature that } \\
\text { enrich professional behavior. Although } \\
\text { it is not obligatory for an employee } \\
\text { to obtain such a set of skills they can be } \\
\text { an additional element that raises the } \\
\text { employee's value. }\end{array}$ & $\begin{array}{l}\text { autonomy, responsibility, social } \\
\text { interaction and personal and professional } \\
\text { development. }\end{array}$ \\
\hline 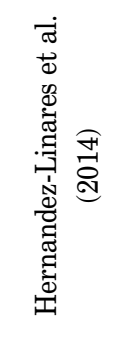 & 2014 & $\begin{array}{l}\text { Transversal competences, also referred } \\
\text { to as global competences, are a set } \\
\text { of competences that can be transferred } \\
\text { to any professional context irrespective } \\
\text { of the situation where they were attained. } \\
\text { They are crucial for all types of work and } \\
\text { are fundamental for more specific "hard" } \\
\text { competences. }\end{array}$ & $\begin{array}{l}\text { Can be divided according to Tuning } \\
\text { Project diversification: } \\
\text { - Instrumental } \\
\text { - Interpersonal } \\
\text { - Systemic or integrative competence }\end{array}$ \\
\hline 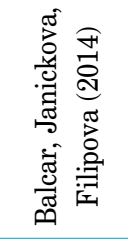 & 2014 & $\begin{array}{l}\text { Transversal competences contain skills, } \\
\text { values and attitudes that help future } \\
\text { employees to obtain a high level of } \\
\text { holistic development and therefore allows } \\
\text { them to adapt to any changes }\end{array}$ & $\begin{array}{l}\text { Leadership skills, the ability to } \\
\text { communicate, problem-solving, the } \\
\text { ability to work as a team and creativity- } \\
\text { related competences }\end{array}$ \\
\hline 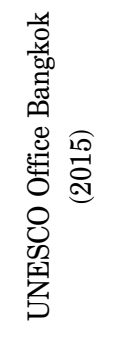 & 2015 & $\begin{array}{l}\text { Transversal competences are skills and } \\
\text { competences that are attained in non- } \\
\text { work-related situation or through } \\
\text { academic disciplines that are not related } \\
\text { to a specific profession. Thus, transversal } \\
\text { competences can be acquired in one } \\
\text { context to solve a task and transferred to } \\
\text { another context. }\end{array}$ & $\begin{array}{l}\text { Skills represented in } 6 \text { domains: } \\
1 \text { Critical and innovative thinking } \\
2 \text { Interpersonal skills } \\
3 \text { Intrapersonal skills } \\
4 \text { Global citizenship } \\
5 \text { Media and information literacy } \\
6 \text { Other }\end{array}$ \\
\hline
\end{tabular}


Cont. table 1

\begin{tabular}{|c|c|c|c|}
\hline Author & Year & Definition & Skills \\
\hline 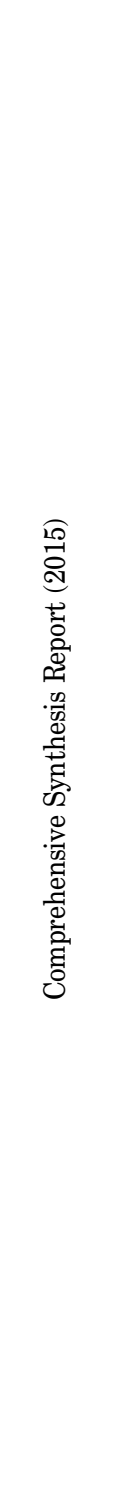 & 2015 & $\begin{array}{l}\text { Transversal competences are considered } \\
\text { as such skills that are not specifically } \\
\text { related to a particular work-related } \\
\text { situation, field or area of knowledge } \\
\text { and academic discipline but can be used } \\
\text { for completing different tasks in any } \\
\text { work settings. }\end{array}$ & $\begin{array}{l}\text { Different lists of TVCs from each } \\
\text { country-partner: Austria } \\
\text { (Communication in the mother tongue } \\
\text { and foreign languages / second language; } \\
\text { Mathematical competence and } \\
\text { competences in science and technology; } \\
\text { Digital competence; Learning to learn; } \\
\text { Social and civic competences; Sense of } \\
\text { initiative and entrepreneurship; Cultural } \\
\text { awareness); Belgium (relational, } \\
\text { organizational competences; linguistic } \\
\text { skills; social behaviour; communication, } \\
\text { coaching and leadership abilities); } \\
\text { Greece (Literacy skills; Strong numeral } \\
\text { and mathematical skills; Fundamental } \\
\text { financial / accounting skills; Fluency in } \\
\text { English and other foreign language } \\
\text { skills; Computer / ICT skills; Emotional } \\
\text { Intelligence related skills; Team-player; } \\
\text { Strong communicating skills; } \\
\text { Management skills); Italy (Learning to } \\
\text { learn; Organizing and planning; } \\
\text { Communication; Collaborating; } \\
\text { Consciousness; Problem Solving; } \\
\text { Identifying links among facts and events; } \\
\text { Ability to collect and analyse } \\
\text { information); Spain (Language } \\
\text { communication; Mathematical } \\
\text { competence and basic skills in science } \\
\text { and technology; Digital competence; } \\
\text { Learning to learn; Civic and social } \\
\text { competences; Sense of initiative and } \\
\text { entrepreneurship; Cultural awareness } \\
\text { and expression); Poland (transversal } \\
\text { competences referred to as a subgroup } \\
\text { of key competences). }\end{array}$ \\
\hline 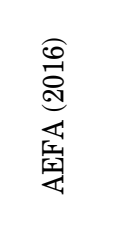 & 2016 & $\begin{array}{l}\text { Transversal competences are } \\
\text { competences that can be mobilized in } \\
\text { different professional situations. }\end{array}$ & $\begin{array}{l}\text { Skills represented in } 5 \text { dimensions: } \\
1 \text { organizational } \\
2 \text { autonomy and adaptability } \\
3 \text { social sphere } \\
4 \text { communication } \\
5 \text { ability to participate and initiate }\end{array}$ \\
\hline
\end{tabular}


Cont. table 1

\begin{tabular}{|c|c|c|c|}
\hline Author & Year & Definition & Skills \\
\hline 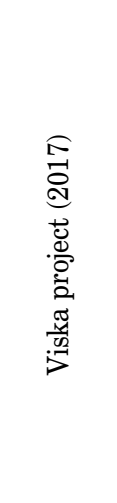 & 2017 & $\begin{array}{l}\text { Transversal competences are considered } \\
\text { as such skills that are not specifically } \\
\text { related to a particular work-related } \\
\text { situation, field or area of knowledge and } \\
\text { academic discipline but can be used for } \\
\text { completing different tasks in any work } \\
\text { settings. }\end{array}$ & $\begin{array}{l}\text { The classification is the same as } \\
\text { UNESCO but adapted with several skills } \\
\text { examples from Key Competences: } \\
1 \text { Critical and innovative thinking, } \\
\text { Ability to learn } \\
2 \text { Interpersonal skills - presentation } \\
\text { and communication skills; both in } \\
\text { mother tongue and in foreign language } \\
4 \text { Global citizenship - social and civic } \\
\text { competence } \\
5 \text { Media and information literacy - } \\
\text { digital competence }\end{array}$ \\
\hline 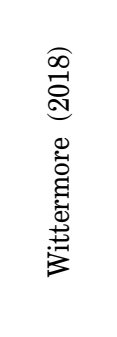 & 2018 & $\begin{array}{l}\text { Transversal competences that can be also } \\
\text { viewed as soft skills, } 21 \text { st century skills, } \\
\text { key competencies, and global } \\
\text { competencies. They are essential for } \\
\text { personal self-development and } \\
\text { improvement of work-related } \\
\text { characteristics; fundamental for applying } \\
\text { any knowledge or skill in a work context. }\end{array}$ & $\begin{array}{l}\text { seven core transversal skills: } \\
\text { Collaborative problem-solving; } \\
\text { Learning to learn, continuing to learn; } \\
\text { Digital competencies and mindset; } \\
\text { Initiative and independent thinking; } \\
\text { Resilience; } \\
\text { Adaptability; } \\
\text { Cultural awareness and expression. }\end{array}$ \\
\hline 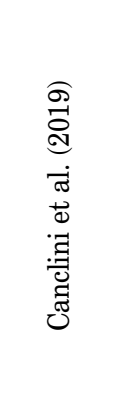 & 2019 & $\begin{array}{l}\text { Transversal competences are skills that } \\
\text { refer to an employee's values of cognitive } \\
\text { and relational nature. They are connected } \\
\text { with specific situation rather than precise } \\
\text { professional activity. TVC can also } \\
\text { transfer acquired skills to different work } \\
\text { contexts. }\end{array}$ & $\begin{array}{l}\text { 1. Ability to work in a group } \\
\text { 2. Knowing how to work independently } \\
\text { 3. Problem solving } \\
\text { 4. Creativity } \\
\text { 5. Initiative skills } \\
\text { 6. Ability to listen } \\
\text { 7. Public speaking ability } \\
\text { 8. Ability to overcome difficulties } \\
\text { 9. Having the ability to synthesize } \\
\text { 10. Flexibility and adaptability }\end{array}$ \\
\hline 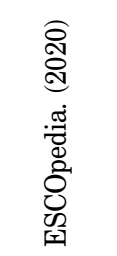 & 2020 & $\begin{array}{l}\text { Transversal competences are the building } \\
\text { blocks for the development of the "hard" } \\
\text { skills and competences required to } \\
\text { succeed on the labour market. They are } \\
\text { often referred to as core skills, basic skills } \\
\text { or soft skills. }\end{array}$ & $\begin{array}{l}\text { application of knowledge } \\
\text { attitudes and values } \\
\text { language } \\
\text { social interaction } \\
\text { thinking }\end{array}$ \\
\hline
\end{tabular}

Source: original compilation by the authors. 
The above definitions take different approaches to describing their characteristics, because the analysis of transversal competencies depends on the areas of activity and the specific training that is required to obtain them. Earlier studies depict transversal competences as an additional set of skills that help a person to develop their specific "hard" skills (Gouvernement du Québec, 2003).

Development of transdisciplinary and transferable competences in future employees is one of the long-term aims of modern educational integration aspects. Thus, the main feature that is similar in many researchers' definitions is that TVCs can be transferred to any work-related situation, irrespective of where and when they were acquired (Balcar, Janickova and Filipova, 2014; Sá and Serpa, 2018, Visca, 2017; Canclini et al. 2019; Simon Wittermore, 2018).

Although some aspects of transversal competences are already harnessed in the educational process, their nature is not homogeneous and requires further study. The issue of transversal competence terminology is unclear, as the very concept continues to evolve. Their value is intensified by the growing need for social and labour realities in which specialized knowledge quickly becomes obsolete, contrary to the ability of applying general knowledge to different situations that is considered a necessary productive strategy in relation to the modern labour market.

The ERI-Net's framework on TVCs, which is the most commonly used by researchers, has six domains: 1) critical and innovative thinking (creativity, entrepreneurship, resourcefulness, application skills, reflective thinking, reasoned decision-making); 2) interpersonal skills (communication skills, organizational skills, teamwork, collaboration, sociability, collegiality, empathy, compassion); 3) intrapersonal skills (self-discipline, ability to learn independently, flexibility and adaptability, self-awareness, perseverance, self-motivation, compassion, integrity, self-respect); 4) global citizenship (awareness, tolerance, openness, responsibility, respect for diversity, ethical understanding, intercultural understanding, ability to resolve conflicts, democratic participation, conflict resolution, respect for the environment, national identity, sense of belonging); 5) media and information literacy (ability to obtain and analyse information through ICT, ability to critically evaluate information and media content, ethical use of ICT); and 6) physical health, religious values (appreciation of healthy lifestyle, respect for religious values) (UNESCO et al., 2015). 
Transversal competences describe knowledge, skills and values that will help future employees to realize themselves as individuals and professionals, as well as to find work, their place in life and society. Therefore, higher education is designed to create conditions for the training of specialists of the innovative type, who have transversal skills that will allow individuals to optimize their work.

Today, health is considered as a personal and public asset, so health care, disease prevention and health promotion are a priority task for each individual and society as a whole. The sixth domain of TVCs comprises "physical health" and "appreciation of healthy lifestyle", which Nutbeam (2000:261) defines as "health and social outcomes" of health literacy. As our literature review has shown, numerous researchers have paid attention to health literacy as "an individual construct", "a personal's ability or capacity", "specific skills required to perform health care related tasks, e.g., making health decisions", "the cognitive and social skills", "motivation to receive health information", "the skills to evaluate and participate in civic action related to health care issues", "communication skills", "the ability to engage in two-way communication", "skills in media literacy and computer literacy", "lay and professional knowledge of health topics, culture", and so on (Berkman, Davis, \& McCormack, 2010). Consequently, we can conclude that definitions of health literacy are in line with the definition of the concept "competence", thus, in our ministudy we refer to health literacy as health literacy competence. The current conceptualization of HLC concerns the domains of TVCs; HLC is one of TVCs and can be cultivated through students' TVCs development; definitions of HLC manifest the deep interrelations between its structure and functions, as well as interrelations of internal and external factors, natural and social ones.

Bowden and Marton (2014) suggest that integration of TVCs as generic competences in the context of higher education should be characterized by the following: a) recognition of TVCs by the given "university community"; b) students' TVCs development during their time at university; c) transcendence of disciplinary knowledge; and d) training graduates as agents whose future activity will benefit the society.

Educators react to the integration of TVCs into university curricula differently. Enthusiasts take into account that TVCs facilitate integrated 
learning across disciplinary boundaries; are intended to improve graduates' employability, training; enhance reflective practice. Sceptics state that the distinction between subject-based and transversal competences (TVCs) is not very clear; TVCs are subject-independent; there is an overlapping link between TVCs; some TVCs are viewed as "traditional" competences. Thus, educators face challenges that require modification of curricula and pedagogy as well as assessment.

\section{Methodology}

The holistic approach of the new educational paradigm is underpinned by the systems approach, which assumes a structural and functional analyses of complex systems in their dynamics and interrelations with other systems. The systems approach reveals a deep picture of the functioning of complex systems from a holistic point of view. TVCs may be viewed as multidisciplinary objects that are learned through inter-, trans- and pluridisciplinary approaches. While structural analysis is aimed at studying isolated static complex systems and functional analysis is oriented toward analysing the functioning of systems outside their development, the systems approach is based on the study of the mechanism of development and functioning of complex systems, the latter being taken in all the richness of interrelationships with other systems.

The participants in this study comprised a group of bachelor's degree students studying management at a local university in Ukraine. Altogether there were 24 students between ages of 18-20.

To confirm the reliability of the obtained results, the following formal methods and techniques were applied: qualimetrics method, statistical method of index assessment and the method of arithmetic average.

\section{Results and Discussions}

Traditionally, the classification of competences is based on a philosophical approach, as subject-object-subject interrelations: 1. Competences relating to the individual as a personality, as an actor of 
everyday life activity (personality development) 2. Competences relating to the interaction of the individual with other people, 3 . Competences relating to the individual's labour activity, manifested in all its types and forms (cited in Vozniuk, 2011). In this research we refer the combination of TVCs (HLC as well) and subject-based competences as universal competences that: are acquired through education; can be embedded and well-balanced in the university curricula; underpin all subjects; can be assessed.

Under the systems approach, the human being is the agent and object of culture who is in the process of creative activity, i.e. an individual actor who creates material and spiritual culture in the socio-cultural context. Communication is the link that connects all the components of culture and sociocultural processes together. Thus, communication is the basis of human interaction, professional interactions as well. As communication competence is the basis to develop students' HLC, we can apply a functionalist perspective on culture to exploring and identifying the methods and strategies to develop TVC in young adults.

As any human activity, cultivating HLC is a specific kind of individual's active attitude to the world, the aim of which is to change and transform the world through assimilation and development of existing forms of culture. The gradual process of internalization of culture forms causes the gradual development of the individual and externalization of his or her actions based upon knowledge. This process represents the process of socialization or enculturation of the individual to culture and predicts his or her ability to be an accepted member of the society. Therefore, cultivating students' HLC should be based on Galperin's theory of internalization and externalization of cognitive activities, that is, the individual's socio-cultural knowledge assimilation (internalization) gradually takes over his or her behaviour patterns (externalization) and makes sense of them.

From the philosophical standpoint, culture is a system of values. We assume that students should be oriented to such individual values as Health, Truth, Goodness while acquiring HLC.

Culture as a system of symbols determines the choice of texts that contain information about health care, disease prevention and health promotion, e.g. prescription bottles, appointment slips, other essential health-related materials, etc. 
The interrelation between communication and culture, e.g. professional and personal interactions; doctor's consultations, etc., requires a dialogic model displayed through initiating, stimulating and terminating interaction. So, students need to be taught consensus-making communication strategies. The interrelation between human activity and culture focuses on interactions with the ecosystems that support our lives (e.g. disputes about environmental pollution, man-made disasters, etc.).

To describe the results achieved by students in terms of HLC, Bloom's, Dave's or Simpson's taxonomies can be applied. Bloom's taxonomy is focused on cognitive and affective domains; Dave's and Simpson's taxonomies can be used by students to observe their progress in the psychomotor domain as they become more competent in health literacy. An example is given in Table 2.

\section{Table 2. An application of Bloom's cognitive domain categories to a student's HLC}

\begin{tabular}{|c|c|}
\hline Level & Definition \\
\hline Knowledge & The student is able to remember information about diabetes \\
\hline Comprehension & The student is able to demonstrate that he or she understands this information \\
\hline Application & $\begin{array}{l}\text { The student is able to use this information in a concrete situations (eat less sugar } \\
\text { and sweets) }\end{array}$ \\
\hline Analysis & $\begin{array}{l}\text { The student gains an understanding of why this information is important to his or } \\
\text { her well-being (the risk of weight gain, high blood pressure) }\end{array}$ \\
\hline Synthesis & $\begin{array}{l}\text { The student is able to use this information to make positive changes in lifestyle } \\
\text { (to appreciate a healthy lifestyle, to keep to a diet) }\end{array}$ \\
\hline Evaluation & $\begin{array}{l}\text { The student is able to make healthy choices based on this information (not to buy } \\
\text { high sugar content processed foods, to engage in exercise) }\end{array}$ \\
\hline
\end{tabular}

Source: Adapted from Castle (2003).

Let us now turn to the table describing the Qualimetric Model of Transversal Skills Cultivating (Table 3). First, we will view the process of working with the qualimetric model of Transversal Skills Cultivating. According to the qualimetric model, its components are specified as the factors of this model, indicated as $F_{i}, i=1, \ldots, 6$, while the values of these factors were indicated as $f_{i}, i=1, \ldots, 6$, where $F_{1}$ is an individual as an actor of life activity (personality development competence), $f_{1}=0.2$; 
$F_{2}$ - global citizenship competence, $f_{1}=0.1$;

$F_{3}$ - interpersonal skills; $f_{1}=0.2$;

$F_{4}$ - communication competence, $f_{1}=0.2$;

$F_{5}$ - the individual as an actor of professional activity (subject-based competence), $f_{1}=0.2$;

$F_{6}-$ media and information literacy competence, $f_{1}=0.1$.

\section{Table 3. The Qualimetric Model of Evaluating Transversal Skills Cultivation}

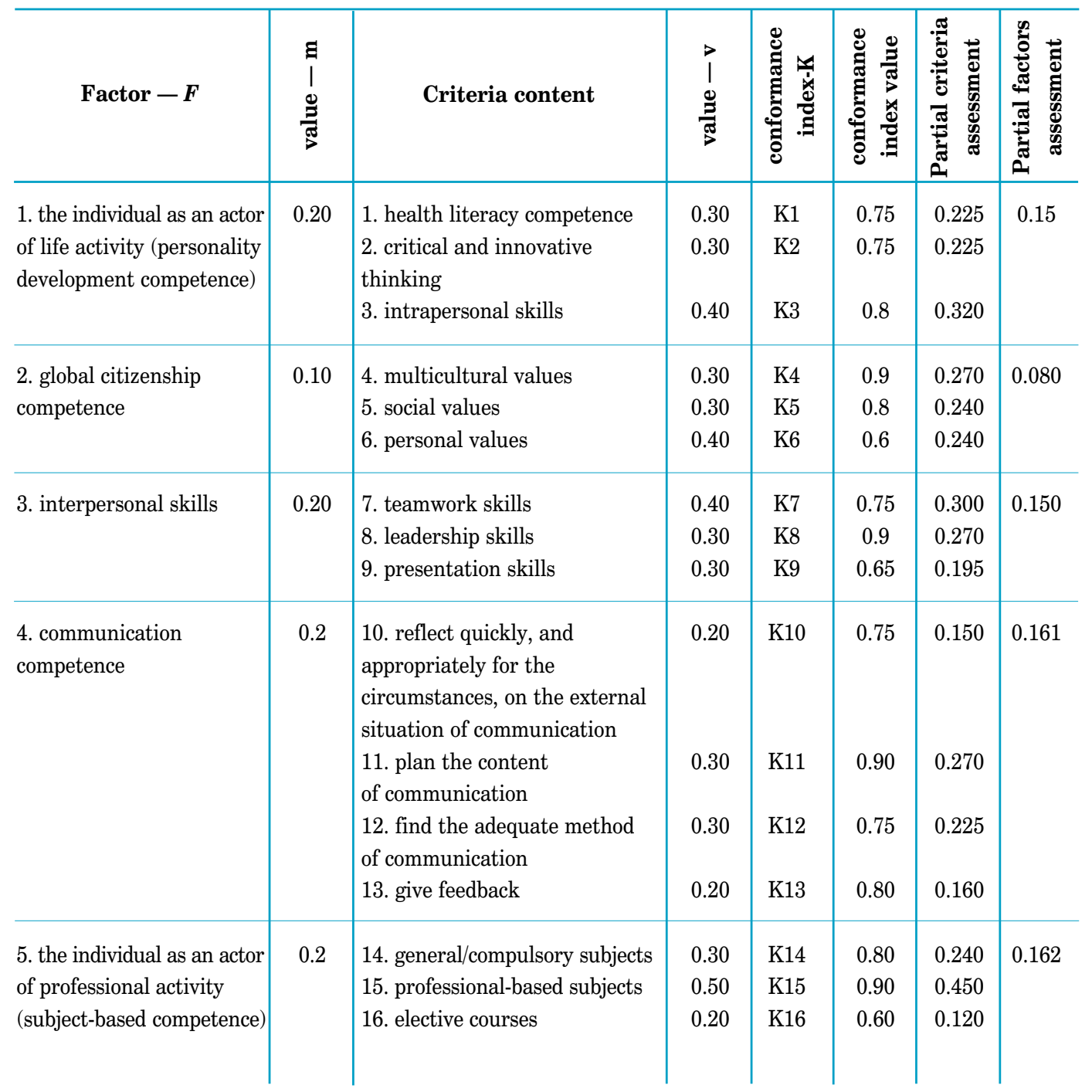




\section{Cont. table 3}

\begin{tabular}{|c|c|c|c|c|c|c|c|}
\hline Factor $-F$ & 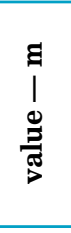 & Criteria content & $\begin{array}{l}\overrightarrow{1} \\
\underset{D}{\mathbb{D}}\end{array}$ & 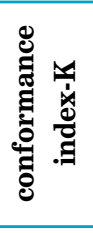 & 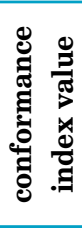 & 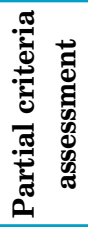 & 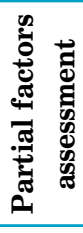 \\
\hline 6. media and information & 0.10 & 17. IT skills & 0.70 & $\mathrm{~K} 17$ & 0.80 & 0.560 & 0.07 \\
\hline literacy competence & & 18. Media and IT Ethics & 0.30 & K18 & 0.45 & 0.135 & \\
\hline $\begin{array}{l}\text { Total assessment } \\
\text { in unit parts }\end{array}$ & 1.00 & & & & & & 0.77 \\
\hline
\end{tabular}

Source: results of author's research

The above mentioned factors and their values are given in the first two columns (Table 4). As an example, let us take factor $F_{1}$. Five criteria of this factor are presented in the second line and the third column (table 4).

\section{Table 4. The Qualimetric Model of Evaluating Transversal Skills Cultivation}

\begin{tabular}{l|c|l|c|c|c|c}
\hline \multicolumn{1}{c|}{ Factor $\boldsymbol{F}_{\boldsymbol{i}}$} & $\begin{array}{c}\text { Factor' } \\
\text { value } \boldsymbol{f}_{\mathbf{1}}\end{array}$ & Criteria content & $\begin{array}{c}\text { conformance } \\
\text { index } \boldsymbol{m}_{\boldsymbol{i}}\end{array}$ & $\begin{array}{c}\text { conformance } \\
\text { index } \\
\text { value } \boldsymbol{k}_{\boldsymbol{i}}\end{array}$ & $\begin{array}{c}\text { criteria } \\
\text { assessment }\end{array}$ & $\begin{array}{c}\text { factors } \\
\text { assessment }\end{array}$ \\
\hline $\begin{array}{l}F_{1}-\text { the individual } \\
\begin{array}{l}\text { as an actor of life } \\
\text { activity (personality } \\
\text { development } \\
\text { competence) }\end{array}\end{array}$ & $F 1=0.2$ & $\begin{array}{l}1 . \text { health literacy } \\
\text { competence } \\
2 . \text { critical and } \\
\text { innovative thinking } \\
3 . \text { intrapersonal skills }\end{array}$ & $m_{1}=0.3$ & 0.75 & 0.225 & $F_{1}=0.15$ \\
\hline
\end{tabular}

The criteria values are defined by the experts and determined as $m_{i}, m_{i}=0.3, i=1,2,3$.

Source: results of original research

The second factor $-F_{2}-$ comprises three criteria, the third one $F_{3}$ includes three, the fourth one $F_{4}$ comprises four, the fifth factor $F_{5}$ includes 
three criteria and the sixth one $F_{6}$ comprises two criteria, making for a total of 18 criteria. The criterion with index i from the third column corresponds to value $m_{i} \varepsilon$ with the same from the fourth column.

A student who evaluates their own activity with the help of this qualimetric model has to assess their activity according to each 18 criteria. The conformance index value is $k_{i}$ for criterion $i$. Experts suggest giving $k_{i}$ the following value: 0.00 - the student does not correspond to a certain level; 0.25 - the student corresponds to a certain level for around $0 \%$ to $40 \%$ of requirements; 0.50 - the student conforms to this level for around $40 \%-60 \%$ of the requirements; 0.75 — the student corresponds to this level for around $61 \%-75 \%$ of requirements; 1.00 - the student conforms to this level for around $76 \%-100 \%$ of requirements.

After a student has completed the table by putting his mark in the fifth column, conformance index value $k_{i}, i=1, \ldots, 18$. Then the factor analysis is calculated - it corresponds to the numbers that characterize the conformity of a student to the defined factors; these numbers are given the same letters $F_{i}, i=1, \ldots, 6$, as the factors are calculated using the formulas:

$$
\begin{aligned}
& F_{1}=f_{1} \sum_{i=1}^{3} k_{i} m_{i}, F_{2}=f_{2} \sum_{i=4}^{6} k_{i} m_{i}, F_{3}=f_{3} \sum_{i=7}^{9} k_{i} m_{i}, F_{4}=f_{4} \sum_{i=10}^{13} k_{i} m_{i}, \\
& F_{5}=f_{5} \sum_{i=14}^{16} k_{i} m_{i}, F_{6}=f_{6} \sum_{i=17}^{18} k_{i} m_{i} .
\end{aligned}
$$

The factor value letters $F_{i}, i=1, \ldots, 6$ is the sum of this factor value $f_{i}, i=1, \ldots, 6$ on the paired sum of the total value sum of its criteria as well as on their conformance index value. If the sum of every criteria conformance index value is 1 , the factor index is less or equal to the factor value.

$$
F_{1} \leq f_{1}, F_{2} \leq f_{2}, F_{3} \leq f_{3}, F_{4} \leq f_{4}, F_{5} \leq f_{5}, F_{6} \leq f_{6} .
$$

The sum of factor indexes $F_{i}, i=1, \ldots, 6$ is considered to be equal to the level of student's transversal skills cultivation and is denoted as: $r=\sum_{i=1}^{6} F_{i}$. If we sum up every component of the last inequality, it will 
be: $\quad r=\sum_{i=1}^{6} F_{i} \leq \sum_{i=1}^{6} f_{i}=1, r \leq 1$, so the level of student's transversal skills cultivation is always less or equal to 1 , and is 1 exactly only in case when all conformance indices values are $k_{i}=1, i=1, \ldots, 18$.

The analysis of questionnaire responses, therefore, made it possible to reveal the level of student's transversal skills cultivation and to pay attention to the specific techniques that show how the skills can be more effectively streamlined. It was found out that most students do not master the communication techniques, interpersonal skills, and have a low level of global citizenship competence as well as health literacy competence. Nevertheless, under the circumstances of the COVID-19 pandemic and future challenges of the modern world, most students reported that they felt that TVCs and HLC, in particular, are vital for their future professional activity. Overall, the majority of the respondents have positive results in such TVCs as: the individual as an actor of professional activity (subjectbased competence), as well as media and information literacy competence.

\section{Conclusions}

This article has focused on the six most significant factors for transversal competence evaluation: 1. the individual as an actor of life activity (personality development competence); 2. global citizenship competence; 3. interpersonal skills; 4 . communication competence; 5 . the individual as an actor of professional activity (subject-based competence); 6. media and information literacy competence. The study was limited to 18 criteria of the abovementioned corresponding factors, and also limited to a relatively small group of management students from a local university. The findings were drawn from qualimetric analysis, and as such, any attempt at generalization of this mini-study should bear these limitations in mind.

The key findings of the study indicate that most students do not consider themselves to have mastered communication techniques or interpersonal skills, and they report that they have a low level of global citizenship competence and health literacy competence. Nevertheless, the respondents report positive results in such transversal competences as: the individual as an actor of professional activity (subject-based competence) as well as media and information literacy competence. 
Overall, the study reveals that despite educators' recognition of TVCs, most students' TVCs development appears to be insufficiently connected to the curricula and to focus mainly on professional competence cultivation. This suggests that current curricula fail to meet the students' needs and expectations to be well equipped to the future challenges, e.g. the current COVID-19 pandemic. The findings from our mini-study thus support the claim that students' TVC development requires a new educational paradigm based on a holistic approach to competence-based learning that involves the harmonious development of a person's TVCs and subject-based competences. For instance, HLC can be cultivated through TVCs on the basis of communication competence.

While this study is limited with respect to its scope, to management students' cultivation of HLC, it is hoped that this work will stimulate further research in the field of other TVCs and HLC development. The experimental results illustrate promising prospects for further research involving researching tools that can develop students' transversal competence.

\section{References}

1. AEFA (2016). Publication d'un guide d'évaluation des compétences transversales [Publication of an evaluation guide for transversal competences] (2016) https:/epale.ec.europa.eu/fr/resourcecentre/content/aefa-publication-dun-guide-devaluation-des-competences-transversales

2. Balcar, J.; Janickova, L.; Filipova, L. (2014) What general competencies are required from the Czech labour force? Prague Econ. Pap., 2, 250-265

3. Berkman, N. D., Davis, T. C., \& McCormack, L. (2010). Health Literacy: What Is It? Journal of Health Communication, 15(2), 9-19. https://doi.org/10.1080/10810730.2010.499985

4. Bowden, J.A., \& Marton F. (2014). The University of learning. Abingdon, Oxon: Routledge.

5. Canclini, T., Mazza, R., Ratti, M., \& Lorenzon C., (2019). "LE SOFT SKILLS" Le competenze trasversali: come giudicano gli studenti la loro formazione scolastica, l'importanza che hanno nel mondo del lavoro e le proprie capacita. ["SOFT SKILLS" Transversal skills: how students rate their education, the importance they have in the world of work and their skills.] http://images.co.camcom.gov.it/f/StudiEconomici/So/Soft_Skills_compet_tras.pdf

6. Castle, A. (2003). Demonstrating critical evaluation skills using Bloom's taxonomy. British Journal of Therapy and Rehabilitation, 10(8), 369-373. https://doi.org/10.12968/bjtr.2003.10.8.13515

7. Comprehensive Synthesis Report on Good Practices and Assessment Tools (2015) http://www.keystart2work.eu/images/docs/KeySTART2Work_SynthesisReport_TCs_GoodPractices AssessmentTools.pdf

8. ESCOpedia. (2020). European multilingual classification of Skills, Competences and Occupations. https://ec.europa.eu/esco/portal/escopedia/Transversal_knowledge_44_skills_and_competences

9. Gouvernement du Québec, Ministre de l'Education (2003), Quebec school training program. Secondary Education, Chapter 3, Transversal Skills.

10. Hernandez-Linares R., Enrique Agudo J., Rico M. and Sánchez H. (2014). Transversal Competences of University Students of Engineering. Croatian Journal of Education. 17(2). 383-409.

11. Nutbeam, D. (2000). Health literacy as a public health goal: a challenge for contemporary health education and communication strategies into the 21st century. Health Promotion International, 15(3), 259-267. https://doi.org/10.1093/heapro/15.3.259 
12. Pârvu, I., Ipate, D. M. (2010) The partnerships between universities - Representatives of the labor market: A solution to improve the professional relevance of university graduates. In Proceedings of the 4th World Congress on the Advancement of Scholarly Research in Science, Economics, Law \& Culture. Addleton Academic Publishers: New York, NY, USA, 145-152

13. Rapoport, A. (1976). General systems theory: A bridge between two cultures. Third annual Ludwig von Bertalanffy memorial lecture. Behavioral Science, 21(4), 228-239.https://doi.org/ 10.1002/bs.3830210404

14. Sá, Maria, and Sandro Serpa. (2018). Transversal Competences: Their Importance and Learning Processes by Higher Education Students. Education Sciences, vol. 8, no. 3, 12

15. Sørensen, K., Van den Broucke, S., Fullam, J., Doyle, G., Pelikan, J., Slonska, Z., \& Brand, H. (2012). Health literacy and public health: A systematic review and integration of definitions and models. BMC Public Health, 12(1). https://doi.org/10.1186/1471-2458-12-80

16. Tuning Academy Reference Points. (2009). Retrieved from Tuningacademy.org website: http://tuningacademy.org/reference-points/?lang=en

17. UNESCO Office Bangkok and Regional Bureau for Education in Asia and the Pacific (2015). 2013 Asia-Pacific Education Research Institutes Network (ERI-Net) regional study on transversal competencies in education policy and practice (phase I): regional synthesis report. Bangkok: UNESCO Bangkok Office.

18. UNESCO Roadmap for Implementing the Global Action Programme on Education for Sustainable Development. (2015). Retrieved October 21, 2018, from Un.org website: https://sustainabledevelopment. un.org/index.php?page $=$ view $\&$ type $=400 \& n r=1674 \&$ menu $=35$

19. VISKA Project (2017). Briefing paper on Transversal Skills Deliverable D1.1. of the https://viskaproject.eu/wp-content/uploads/2018/02/D1.1_TS_VISKA_FINAL.pdf

20. Vozniuk O. (2011). Kompetentnist fakhivtsia u svitli systemno-fraktalnoho pidkhodu [Competence of a specialist from a system-fractal perspective]. in Profesiina pedahohichna osvita: kompetentnisnyi pidkhid: monohrafiia za red. O. Dubaseniuk. [Professional Pedagogical Education: Competency based Approach: Monograph, edited by O. Dubaseniuk]. Zhytomyr: Vyd-vo ZhDU im. I. Franka, 2011. pp. 371-386

21. Whittermore, S. (2018). Transversal Competencies for Future Proofing the Workforce. White paper. Skilla, 48.

\section{Tetyana Borova, Doctor of Sciences (Pedagogy), Professor, Simon Kuznets Kharkiv National University} of Economics, Ukraine - Head of the Department of Pedagogy, Foreign Philology and Translation. Her research interests include problems of education management, educational coaching, communication and its influence on staff professional development.

Prof Viktoriia Petrenko, PhD, Simon Kuznets Kharkiv National University of Economics, Ukraine — PhD in Pedagogical sciences, Associate Professor of the Department of Pedagogy, Foreign Philology and Translation. Her research interests include problems of didactics, educational theory and instructional design.

Tetiana Ved, PhD student, Simon Kuznets Kharkiv National University of Economics, Ukraine - PhD student in Pedagogical sciences of the Department of Pedagogy, Foreign Philology and Translation. Her research interests include problems of the transversal competence approach and future managers' competences.

Vasiliy Pyvovarov, PhD, Yaroslav Mudryi National Law University, Ukraine - Candidate of Philology, Associate Professor of the Department of Cultural Studies. His research interests include problems of training of specialists according to the competence approach, language of law, modern issues of linguistics, development of universities. 